\title{
Quality of Jatropha curcas L. Seeds Harvested at Different Stages of Fruit Maturation
}

\author{
Cristiane de Oliveira Veronesi ${ }^{1}$, Cristiano Marcio Alves de Souza1, \\ Ademar Pereira Serra2*, Leidy Zulys Leyva Rafull11, Cesar José da Silva ${ }^{3}$, \\ Vinicius de Vito Ros' ${ }^{1}$, Vanessa do Amaral Conrad ${ }^{1}$ \\ ${ }^{1}$ Federal University of Grande Dourados (UFGD_Universidade Federal da Grande Dourados), \\ Dourados, Brazil \\ ${ }^{2}$ Embrapa Beef Cattle, Campo Grande, Brazil \\ ${ }^{3}$ Embrapa Western Agriculture, Dourados, Brazil \\ Email: ademar.serra@embrapa.br
}

Received 8 June 2014; revised 17 July 2014; accepted 6 August 2014

Copyright (C) 2014 by authors and Scientific Research Publishing Inc.

This work is licensed under the Creative Commons Attribution International License (CC BY). http://creativecommons.org/licenses/by/4.0/

(c) (i) Open Access

\section{Abstract}

The aim of this study was to evaluate the physiological quality of Jatropha curcas L. seeds harvested at different stages of fruit maturation and two threshing methods. To analyze the mechanical damage rate an experiment was carried out with five stages of fruit maturation (green, yellow, ripe, dried on the ground and dried on the plant) threshed mechanically and manually. To evaluate the physiological quality, three tests were made; germination, vigor and electrical conductivity, all of them were applied in each storage (0,120 and 240 days after harvest) and five stages of fruit maturation. It was feasible to infer that the maturation stage of yellow, ripe and dried on the plant fruits showed the best results of the physiological quality of the Jatropha curcas L. seeds. The manual threshing is also recommended in order to preserve the physiological quality of Jatropha curcas $\mathrm{L}$. seeds. When the fruits were harvested at the appropriate stage of maturation (yellow, ripe and dry fruit on the plant) and threshing without mechanical damage, the Jatropha curcas $\mathbf{L}$. seeds are possible to store for $\mathbf{2 4 0}$ days without loss in their germination. Regardless of the threshing system and the maturation stage, the seeds of Jatropha curcas $L$. lost their vigor from 120 days after harvested, when these seeds were stored in the shadow and in an environment without control on the relative humidity and air temperature.

${ }^{*}$ Corresponding author.

How to cite this paper: Veronesi, C.O., de Souza, C.M.A., Serra, A.P., Rafull, L.Z.L., da Silva, C.J., Ros, V.V. and Conrad, V.A. (2014) Quality of Jatropha curcas L. Seeds Harvested at Different Stages of Fruit Maturation. American Journal of Plant Sciences, 5, 2716-2725. http://dx.doi.org/10.4236/ajps.2014.518287 


\section{Keywords}

\section{Vigor, Harvester, Electrical Conductivity, Germination}

\section{Introduction}

Because of the impact of environmental pollution by the emission of gas from petroleum, it is necessary the development of sustainable technology to produce alternative source of fuel. As an example it is feasible to mention the use of biofuel that is obtained from vegetable oil, source of animal fat and the oil used to cook food.

Brazil has a large number of plants varieties from the Euforbiaceas family. It is possible to extract vegetable oil from these plants to produce biofuel in large scale. The Jatropha curcas L. is quite important alternative to extract oil in large amount to produce biofuel in Brazil. Jatropha curcas L. belongs to the Euforbiaceas family, the same family of Manihot esculenta. So far, the studies about Jatropha curcas L. more focus on chemical properties, medicinal use, and little in agronomic studies [1].

Studies about the moment of harvest of the Jatropha curcas L. fruits to produce seeds must be developed, because it is one of the most important moments to determine the yield of the crop. The challenge of this crop is related with the fruit maturation and the mechanization of the harvest [2]. The mechanization of the harvest must be used to turn a larger sustainable production scale. This mechanization process is essential to optimize the field activities and reduction of production cost. The process of threshing is quite important to maintain the seed quality, especially in mechanical threshing, because in this process it may cause damage of the seed due to the impact of the seed through the machine. The mechanical threshing can cause physical damage and decrease in germination and vigor of the seed, and it is feasible to cause internal damage that, although not visible, can affect seed quality during storage [3].

The application of germination test is quite used to determine the potential of germination in seed lot storage in adequate condition [4]. On the other hand, it is important to emphasis that in Seed Rules of Analysis [5] there is no pattern method known established for Jatropha curcas L. and even in the International Seeds Testing Association [6]. By this point of view, it is important to work in scientific research for this crop.

The vigor test is also used to assess the seed, physiologically being more aware than germination test [7]. Because of the objectivity and swiftness, the electrical conductivity is considered the main vigor test by International Seed Testing Association [6]. Nevertheless, it is necessary to take care of the electrical conductivity test, because many factors can affect its results. The quality of water, temperature, soaking time, water content, the amount of seed tested and genotypes are some factors capable to damage the results of the electrical conductivity test [8]-[11].

Due to the lack of information about the physiological quality of the Jatropha curcas L. seed harvest in manual and mechanical process, this research was proposed. The aim of this research was to evaluate the seed's physiological quality of Jatropha curcas L. harvested in different stages of fruit maturation and storage time in two threshing process, manual and mechanical.

\section{Material and Methods}

\subsection{Data Source}

The experiment was carried out in two different localities. One experimental area was located in the Brazilian Agricultural Research Corporation (EMBRAPA), followed by geographic coordinates, $22^{\circ} 14{ }^{\prime} \mathrm{S}, 54^{\circ} 9^{\prime} \mathrm{W}$, and mean altitude $452 \mathrm{~m}$.

The other experimental area was on a farm followed by geographic coordinates, $22^{\circ} 144^{\prime} 45^{\prime \prime S}, 54^{\circ} 55^{\prime} 18^{\prime \prime} \mathrm{W}$, and mean altitude $446 \mathrm{~m}$. Both experimental areas belong to the municipality of Dourados, state of South Mato Grosso, Brazil. The soil of the study area was predominantly classified as Oxisol [12], the landscape is covered by savanna. The weather condition is classified in Cwh, according to Köppen-Geiger. The mean temperature annual is $18^{\circ} \mathrm{C}$ with a dry winter.

The preparation of the sample and the physiological quality test of the Jatropha curcas L. seed were performed in lab of Machinery and Agricultural Mechanization, and the seed analysis in the lab of seed, both labs 
belongs to the Faculdade de Ciências Agrárias of Universidade Federal da Grande Dourados (FCA/UFGD), in Brazil.

\subsection{Harvesting and Drying the Fruits}

The Jatropha curcas L. fruits were harvested manually, separated by maturation stage, based at the coloration of the fruits and weight. The harvested fruits were let to dry on the floor naturally ventilated. The following step was to determine the humidity of the fruits by the method of stove to $105^{\circ} \mathrm{C} \pm 3^{\circ} \mathrm{C}$ remaining during 24 hours [5], right after the fruits were classified following the criterion of color and content of water. This classification determined five classes of fruits: green fruits, with $87 \%$ of water; yellow fruits, with $59 \%$ of water; yellow fruits with brownish spot (ripe), with $60 \%$ of water; black fruits (dried on the ground), with $9 \%$ of water; and the black fruits (dried on the plant), with $9 \%$ of water.

\subsection{Threshing and Storage}

The threshing machine used was the model Heger GbR-ZaberstraBe 26, this electrical machine was 5 hp (Horsepower-hp), constituted of carbon iron, being made by one hopper, two smooth rolls the spin in opposite direction in 40 turns/minutes, with opening of 1.0 inches, discharge of the shells and seeds, one system of power transmission strap and a support basis. It was allocated 15 liters of fruits into the machine and right after it was performed the selection of these seeds.

In the manual threshing the seeds were separated from their fruits manually. The whole seeds selected were storage in multilayer paper bag in control of laboratory condition. Between the months of August/2009 and March/2010, the mean of the air humidity and temperature were $64 \%$ and $17^{\circ} \mathrm{C}$, respectively.

\subsection{Features of the Jatropha curcas L. Fruits and Seeds}

The next step was to evaluate the features of the fruits and seeds of Jatropha curcas L. It was measured the length and diameter of fruits with the assistance of caliper rule. The vigor test (the first germination count 5 days after sowed), electrical conductivity and the weight of 100 seeds were measured.

The mechanical damage of the seeds caused by fruits threshing was evaluated in the system of manual and mechanical threshing of fruits. This evaluation was determined in 5 maturation stages of the fruits (green, yellow, ripe, dried on the ground and dried on the plant). To determine the visible mechanical damage, it was used one sample with 200 grams of seeds. Based on this sample, it was removed and weighted the broke seeds and seeds with damage on their integument. This procedure was needed to determine the percentage of damage seeds. The index of mechanical damage was determined according to the Equation (1):

$$
D_{m}=100 \frac{m_{d}}{m_{a}}
$$

what, $D_{m}$ —index of mechanical damage, $\% ; m_{d}$-mass of seed with mechanical damage, gram (g); $m_{a}$ —mass of initial sample of seed, gram (g).

The analysis of electrical conductivity was performed using two repetitions with 25 whole seeds, being weighted and placed into plastic cup that supported $200 \mathrm{ml}$ of volume. The following step was to add $75 \mathrm{ml}$ of deionized water and the samples were remained for 24 hours in chamber with $25^{\circ} \mathrm{C}$ [10]. The calculation of the electrical conductivity was determined according to the Equation (2):

$$
E C=\frac{R_{e c}}{m_{s}}
$$

what, EC-electrical conductivity of the soaking solution, $\mu \mathrm{S} \cdot \mathrm{cm}^{-1} \cdot \mathrm{g}^{-1} ; R_{e c}$-reading of the electrical conductivity of seed soaking; $m_{s}$-mass of 25 seeds, gram (g).

\subsection{Statistical Analysis}

In the germination test, the substrate to sow was the "Germitest" paper. This substrate was humidified with deionized water, using the quantitative of 2.5 times the weight of the dry paper [5]. In each repetition of the treatment were sowed 25 seeds, with 8 repetitions per treatment. The seeds were allocated in regulated germination 
in the temperature of $25^{\circ} \mathrm{C}$ and the evaluation was fulfilled at 10 days after sowed. The evaluation of the normal seedling was defined when the seedling had two seminal roots and major root higher than 1.95 inches.

The treatments were composed by seeds harvested in different stage of fruits maturation (green, yellow, ripe, dried on the ground and dried on the plant) and two methods of threshing, being manual and mechanical. The affect of mechanical damage was studied in three different times of storage $(0,120$ and 240 days after threshing).

To carry out the test of mechanical damage, germination and vigor (first count of germination after 5 days of sowed), it was adopted the completely randomized design. To test the mechanical damage, the experimental designed was arranged in a factorial $5 \times 2$, with three repetitions, and the vigor test was conducted in a split plot design.

The data were submitted to analysis of variance (ANOVA) and the mean compared using the Tukey test at $5 \%$ of probability and $t$-test of Student at $5 \%$ of probability. Statistical analysis was performed using the program SPSS for Windows, version 11.0.0 [13].

\section{Results and Discussion}

The physics feature of the fruits and seeds of Jatropha curcas L. in different maturation stages are shown on Table 1 and Table 2. The results showed that the length of green fruits were smaller than the other maturation stages of the fruits. The diameter of the fruits was not different $(P>0.05)$ among the maturation stages. The smaller length of the green fruits indicated that the accumulation of the biomass was not completed yet.

In morphological analysis, [14] obtained the mean of 1.21 inches for length of Jatropha curcas L. fruits. [15] found values of fruit length between 0.984 to 1.575 inches, despite the value of green fruits (Table 1), the other length of fruit is inside this range. The authors cited above used dried fruits to measure the length, this way it is feasible to observe that the green fruits in this work were not completely formed, because of the length obtained.

The seeds that were extracted from the green fruits showed a smaller length and weight mass of 100 seeds. The green and yellow maturation stage showed the smaller thickness of the seed, but no significant difference ( $\mathrm{P}$ $<0.05$ ) was observed in the thickness of the seed in the rest of the maturation stage (Table 2). The thickness of the seed found by [14] was 0.185 inches, which is smaller than all the values showed in this work (Table 2). It is

Table 1. The mean valueof physic feature of Jatropha curca L. fruits.

\begin{tabular}{ccc}
\hline \multirow{2}{*}{ Maturation stage of the fruits } & \multicolumn{2}{c}{ Physics feature $^{\mathrm{a}}$} \\
\cline { 2 - 3 } & $\begin{array}{c}\text { Length of the fruits } \\
\text { (inches) }\end{array}$ & $\begin{array}{c}\text { Diameter of the } \\
\text { fruits (inches) }\end{array}$ \\
Green & $0.948 \mathrm{~b}$ & $0.815 \mathrm{a}$ \\
Yellow & $1.030 \mathrm{a}$ & $0.846 \mathrm{a}$ \\
Ripe & $1.010 \mathrm{a}$ & $0.811 \mathrm{a}$ \\
Dried on the plant & $1.041 \mathrm{a}$ & $0.835 \mathrm{a}$ \\
Dried on the ground & $1.065 \mathrm{a}$ & $0.839 \mathrm{a}$ \\
\hline
\end{tabular}

${ }^{\mathrm{a}}$ Mean in each column followed by the same letter are not significantly different at $\mathrm{P}<0.05$ according to the Tukey test of mean.

Table 2. The mean value of physic feature of Jatropha curca L. fruits.

\begin{tabular}{|c|c|c|c|c|}
\hline \multirow[b]{2}{*}{ Maturation stage of the fruits } & \multicolumn{3}{|c|}{ Physics feature $^{a}$} & \multirow[b]{2}{*}{$\begin{array}{c}\text { Mass of } 100 \text { seeds } \\
\text { (g) }\end{array}$} \\
\hline & $\begin{array}{l}\text { Length of the seeds } \\
\text { (inches) }\end{array}$ & $\begin{array}{l}\text { Thickness of the seeds } \\
\text { (inches) }\end{array}$ & $\begin{array}{l}\text { Width of the seeds } \\
\text { (inches) }\end{array}$ & \\
\hline Green & $0.679 \mathrm{~b}$ & $0.312 \mathrm{~b}$ & $0.425 \mathrm{a}$ & $24.137 \mathrm{~b}$ \\
\hline Yellow & $0.710 \mathrm{a}$ & $0.320 \mathrm{ab}$ & 0.429 a & 26.345 a \\
\hline Ripe & $0.714 \mathrm{a}$ & 0.335 a & 0.425 a & 26.879 a \\
\hline Dried on the plant & $0.733 \mathrm{a}$ & $0.332 \mathrm{a}$ & $0.410 \mathrm{a}$ & 25.799 a \\
\hline Dried on the ground & 0.733 a & 0.335 a & $0.433 \mathrm{a}$ & 26.933 a \\
\hline
\end{tabular}

${ }^{\mathrm{a}}$ Mean in each column followed by the same letter are not significantly different at $\mathrm{P}<0.05$ according to the Tukey test of mean. 
possible to infer that the harvest of the green fruits can damage the accumulation of the biomass in the seed, because in this stage of maturation the process is not completed yet. The width of the seeds showed no difference $(\mathrm{P}>0.05)$ during the maturation stage. All the length of the seed showed in Table 2 was smaller than the results found by [14] who obtained 0.930 inches in mean for length of the seeds.

The highest index of mechanical damage in the seeds was observed in the fruits harvested green and dried on the ground. There was no difference $(\mathrm{P}>0.05)$ among the indexes of mechanical damage in other maturation stages (Figure 1). It is possible to infer that the fruits dried on the ground were already in process of damage, what makes the weakness of the seeds resulting in an increase of the index of mechanical damage. There is a relationship between the dehydration of fruit pericarp and the seed dehydration, this way; it is possible to consider that the driest the fruit higher is the possibility to cause damage on the seeds during the process of harvest, it occurs because of the loss of elasticity making the seed more vulnerable to be damaged [16].

In respect to the green fruits, the most negative impact that causes the largest percentage of mechanical damage was the incomplete process of physiological maturation. These seeds from green fruits showed to be weaker to resist to the mechanical damage than the yellow, dried on the plant or ripe fruits. The right moment to harvest the fruits would be when the fruits reach the physiological maturation; this stage is characterized by the release of the seed from the mother plant [17]. However, the content of the water during the physiological maturation is higher, it can increase the mechanical damage on the seeds during the process of harvest and threshing.

The electrical conductivities in soaking solution of seeds were determined for the seeds storage after the harvest. In the zero day after the harvest the electrical conductivities values do not differ $(P>0.05)$ between the types of threshing for the green fruits and fruits dried on the plant (Table 3), on the other hand, the yellow, ripe and dried fruits on the ground showed difference between the types of threshing, the mechanical threshing showed higher values of electrical conductivities in the soaking solution. That is feasible to infer that the machine caused damage in the seeds, but this damage may be reduced when the fruits are threshing in the maturation stage of dried on the ground and dried on the plant. Even in the manual threshing, there is damage in the seeds. This damage is higher when the fruits are harvested in the maturation stage of green.

In 120 days after harvest, despite the yellow fruits, there was no difference $(P>0.05)$ between the types of threshing. When the type of threshing was manual, the seeds from the green fruits showed the higher values of electrical conductivity (Table 3). In respect to the mechanical threshing, the seed from the yellow fruits reached the higher value of electrical conductivity in soaking solution (Table 3).

In 240 days after harvest, there was significant difference $(\mathrm{P}<0.05)$ between manual or mechanical threshing in the electrical conductivity in the seeds from yellow or ripe fruits. However, the seeds from the dried fruits on the ground and on the plant showed no significant difference $(\mathrm{P}>0.05$ ) between the types of threshing (Table 3).

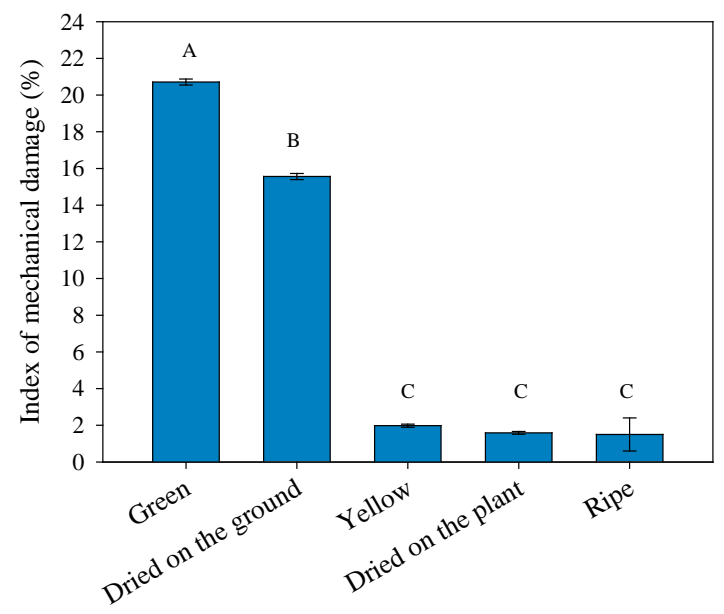

Figure 1. Indices of mechanical damage in the Jatropha curcas L. seeds obtained in different maturation stages and submitted to mechanical threshing. Mean in each bar followed by the same letter are not significantly different at $\mathrm{P}=0.05$ according to the Tukey test of mean. 
Table 3. Mean of electrical conductivity $\left(\mu \mathrm{S} \cdot \mathrm{cm}^{-1} \cdot \mathrm{g}^{-1}\right)$ of the Jatropha curcas L. seeds in soaking solution obtained from fruits in different stages of maturation and time of storage (days after harvest).

\begin{tabular}{|c|c|c|c|c|c|}
\hline \multirow{2}{*}{ Types of threshing } & \multicolumn{5}{|c|}{ Maturation stage of the fruits ( 0 day after harvest $)^{\mathbf{a}}$} \\
\hline & Green & Yellow & Ripe & Dried on the ground & Dried on the plant \\
\hline Manual & $0.138 \mathrm{aA}$ & $0.109 \mathrm{bcB}$ & $0.126 \mathrm{abB}$ & $0.095 \mathrm{cB}$ & 0.102 bcA \\
\hline \multirow[t]{3}{*}{ Mechanical } & $0.145 \mathrm{bA}$ & $0.180 \mathrm{aA}$ & $0.169 \mathrm{aA}$ & $0.124 \mathrm{bA}$ & $0.099 \mathrm{cA}$ \\
\hline & \multicolumn{5}{|c|}{ Maturation stage of the fruits (120 days after harvest $)^{\mathbf{a}}$} \\
\hline & Green & Yellow & Ripe & Dried on the ground & Dried on the plant \\
\hline Manual & $0.125 \mathrm{aA}$ & $0.099 \mathrm{bB}$ & $0.113 \mathrm{abA}$ & $0.087 \mathrm{bA}$ & $0.091 \mathrm{bA}$ \\
\hline \multirow[t]{3}{*}{ Mechanical } & $0.132 \mathrm{abA}$ & $0.162 \mathrm{aA}$ & $0.132 \mathrm{abA}$ & $0.102 \mathrm{bA}$ & $0.096 \mathrm{cA}$ \\
\hline & \multicolumn{5}{|c|}{ Maturation stage of the fruits (240 days after harvest) ${ }^{a}$} \\
\hline & Green & Yellow & Ripe & Dried on the ground & Dried on the plant \\
\hline Manual & $\mathrm{X}$ & $0.223 \mathrm{aB}$ & $0.227 \mathrm{aB}$ & $0.178 \mathrm{bA}$ & $0.187 \mathrm{bA}$ \\
\hline Mechanical & $0.284 \mathrm{a}$ & $0.310 \mathrm{aA}$ & $0.263 \mathrm{aA}$ & $0.196 \mathrm{bA}$ & $0.188 \mathrm{bA}$ \\
\hline
\end{tabular}

${ }^{\mathrm{a}}$ Mean followed by the same capital letters in the column do not differ according to T-test $(\mathrm{P}=0.05)$. Mean in each line followed by the same lower case letter are not significantly different at $\mathrm{P}=0.05$ according to the Tukey test of mean. X-lost treatment.

The mechanical threshing caused damage in the seeds from green, yellow and ripe fruits, this damage was higher than manual threshing.

The results of electrical conductivity indicated that the seeds from the green fruits showed no ideal organization in the system of membrane, this way the results of electrical conductivity were higher in this stage of maturation. According to [18], when the process of the physiological maturation is reached there is a reduction of the electrical conductivity because of the best organization of the membrane system.

The electrical conductivity showed no statistical difference $(P>0.05)$ between the zero day after harvest and 120 days after harvest in all maturation stage. These results were similar among the types of threshing. However, 240 days after the harvest the results of electrical conductivity was statistically different $(\mathrm{P}<0.05)$ among the other periods of storage ( 0 and 120 days after harvest) (Table 4). These results may be possible because of the respiration process occurring through the use of energy source into the seeds storage after 120 day from harvest, this process may damage the seeds and increase the electrical conductivity into the soaking solution. As reported by [19], the electrical conductivity of Cedrela fissilis Vell. seeds increased from 0 day after harvest to 12 months after the harvest, because of their damage of physiological quality over the time of storage.

Compared with the stages of fruits maturation, the seeds from the harvested green, yellow and dried on the plant fruits showed higher value of the vigor test (count of germination after 5 days of sowed) and the fruits dried on the ground reached the low values of vigor test (Table 5). The fruits harvested green, yellow and dried on the plant were in a complete process of maturation, this way it was possible to show the best result in vigor test. The physiological maturation of Jatropha curcas L. seeds occur when the fruits are dried [20].

The values of the vigor decrease over the storage time of the seeds (Table 5). The seeds with zero day of storage got the higher value of vigor, on the other hand the seeds storage for 240 days showed the low value of vigor. In agreement with [21], the Jatropha curcas L. seeds storage until 40 days obtained better viability than seeds storage for 66 to 164 days, that is because of the seed damage over the time.

As regards the threshing types, both seeds, from yellow and dried on the ground fruits reached the low value of vigor in the mechanical threshing (Table 6). This result about the seeds from fruits dried on the ground is because of the damage process in the seeds from these fruits dried on the ground that had already initiated. The explanation about the low vigor of the seeds from yellow fruits is probability because of the higher content of water in these seeds.

The mechanical threshing can become the process of threshing more efficient, but the process of damage can be more intensified and this process decreases the vigor of the seed. The physiological potential of the seeds from fruits dried on the ground were provided by the electrical conductivity in soaking solution, these test results showed decrease in the physiological potential of the Jatropha curcas L. seeds from these fruits mechani- 
Table 4. Mean of electrical conductivity $\left(\mu \mathrm{S} \cdot \mathrm{cm}^{-1} \cdot \mathrm{g}^{-1}\right)$ of the Jatropha curcas L. seeds soaking solution obtained from types of threshing and storage time.

\begin{tabular}{|c|c|c|c|}
\hline \multirow{2}{*}{ Types of threshing } & \multicolumn{3}{|c|}{ Storage time in days (Green fruits) ${ }^{\mathrm{a}}$} \\
\hline & 0 day & 120 day & 240 day \\
\hline Manual & 0.138 a & $0.125 \mathrm{a}$ & $\mathrm{X}$ \\
\hline \multirow[t]{3}{*}{ Mechanical } & $0.144 \mathrm{~b}$ & $0.132 \mathrm{~b}$ & $0.284 \mathrm{a}$ \\
\hline & \multicolumn{3}{|c|}{ Storage time in days (Yellow fruits) ${ }^{\mathbf{a}}$} \\
\hline & Zero day & 120 day & 240 day \\
\hline Manual & $0.109 \mathrm{~b}$ & $0.099 \mathrm{~b}$ & $0.223 \mathrm{a}$ \\
\hline \multirow[t]{3}{*}{ Mechanical } & $0.180 \mathrm{~b}$ & $0.162 \mathrm{~b}$ & $0.310 \mathrm{a}$ \\
\hline & \multicolumn{3}{|c|}{ Storage time in days (Ripe fruits) ${ }^{\mathbf{a}}$} \\
\hline & Zero day & 120 day & 240 day \\
\hline Manual & $0.126 \mathrm{~b}$ & $0.113 \mathrm{~b}$ & $0.227 \mathrm{a}$ \\
\hline \multirow[t]{3}{*}{ Mechanical } & $0.169 \mathrm{~b}$ & 0.132 c & $0.263 \mathrm{a}$ \\
\hline & \multicolumn{3}{|c|}{ Storage time in days (Dried on the ground fruits) ${ }^{\mathbf{a}}$} \\
\hline & Zero day & 120 day & 240 day \\
\hline Manual & $0.095 \mathrm{~b}$ & $0.087 \mathrm{~b}$ & $0.178 \mathrm{a}$ \\
\hline \multirow[t]{3}{*}{ Mechanial } & $0.124 \mathrm{~b}$ & $0.102 \mathrm{~b}$ & $0.196 \mathrm{a}$ \\
\hline & \multicolumn{3}{|c|}{ Storage time in days (Dried on the plant fruits) ${ }^{\mathbf{a}}$} \\
\hline & Zero day & 120 day & 240 day \\
\hline Manual & $0.102 \mathrm{~b}$ & $0.091 \mathrm{~b}$ & $0.187 \mathrm{a}$ \\
\hline Mechanial & $0.099 \mathrm{~b}$ & $0.097 \mathrm{~b}$ & $0.188 \mathrm{a}$ \\
\hline
\end{tabular}

${ }^{\mathrm{a}}$ Mean in each line followed by the same lower case letter are not significantly different at $\mathrm{P}=0.05$ according to the Tukey test of mean. $\mathrm{X}-\mathrm{lost}$ treatment.

Table 5. The mean of vigor test (\%) of Jatropha curcas L. seeds in different maturation stage of the fruits and storage time.

\begin{tabular}{ccccc}
\hline \multirow{2}{*}{ Maturation stage } & \multicolumn{3}{c}{ Storage time $^{\mathrm{a}}$} \\
\cline { 2 - 4 } & 0 day & 120 day & 240 day & Mean \\
\hline Green & $78.00 \mathrm{aB}$ & $75.33 \mathrm{aA}$ & $45.07 \mathrm{bB}$ & $66.13 \mathrm{~B}$ \\
Yellow & $81.17 \mathrm{aAB}$ & $73.33 \mathrm{aA}$ & $69.67 \mathrm{bAB}$ & $74.72 \mathrm{AB}$ \\
Ripe & $85.50 \mathrm{abA}$ & $81.17 \mathrm{abA}$ & $68.67 \mathrm{bAB}$ & $78.45 \mathrm{~A}$ \\
Dried on the ground & $64.83 \mathrm{aB}$ & $55.50 \mathrm{aB}$ & $60.83 \mathrm{aAB}$ & $60.39 \mathrm{~B}$ \\
Dried on the plant & $86.50 \mathrm{aA}$ & $84.83 \mathrm{aA}$ & $77.00 \mathrm{aA}$ & $81.75 \mathrm{~A}$ \\
Green & $78.00 \mathrm{aB}$ & $75.33 \mathrm{aA}$ & $45.07 \mathrm{bB}$ & $66.13 \mathrm{~B}$ \\
Mean & $79.2 \mathrm{a}$ & $71.33 \mathrm{a}$ & $64.25 \mathrm{~b}$ & \\
\hline
\end{tabular}

${ }^{a}$ Mean in each line followed by the same lower case letter are not significantly different at $\mathrm{P}=0.05$ according to the Tukey test of mean. Mean in each column followed by the same capital letter are not significantly different at $\mathrm{P}=0.05$ according to the Tukey test of mean.

Table 6. Mean values of vigor test (\%) of Jatropha curcas L. Seeds in manual and mechanical threshing and different stage of fruits maturation.

\begin{tabular}{|c|c|c|c|c|c|c|}
\hline \multirow{2}{*}{ Types of threshing } & \multicolumn{6}{|c|}{ Maturation stage of the fruits ${ }^{\mathbf{a}}$} \\
\hline & Green & Yellow & Ripe & Dried on the ground & Dried on the plant & Mean \\
\hline Manual & $64.16 \mathrm{bA}$ & $88.22 \mathrm{aA}$ & $80.22 \mathrm{aA}$ & $69.78 \mathrm{bA}$ & $82.11 \mathrm{aA}$ & $76.9 \mathrm{~A}$ \\
\hline Mechanical & 68.11abA & $61.22 \mathrm{bB}$ & 76.67abA & $51.00 \mathrm{cB}$ & $83.44 \mathrm{aA}$ & $68.1 \mathrm{~B}$ \\
\hline Mean & $66.14 \mathrm{~b}$ & $74.72 \mathrm{ab}$ & $78.45 \mathrm{a}$ & $60.39 \mathrm{~b}$ & $82.78 \mathrm{a}$ & \\
\hline
\end{tabular}

${ }^{a}$ Mean in each line followed by the same lower case letter are not significantly different at $\mathrm{P}=0.05$ according to the Tukey test of mean. Mean in each column followed by the same capital letter are not significantly different at $\mathrm{P}=0.05$ according to the Tukey test of mean. 
cal threshing. According to [11], the physiological potential of the seeds can be evaluated by the results of electrical conductivity and when it's higher the electrical conductivity the lower the physiological potential of the seeds will be.

There was no difference $(\mathrm{P}>0.05)$ among the germination test of the seeds from yellow, ripe and dried on the plant fruits, in respect of storage time. The seeds from green fruits attained the low value of germination in 240 days of storage (Table 7).

The seeds from the yellow, ripe and dried on the plant fruits obtained higher germination than the other seeds from the other stages of fruit maturation. In these results, the seeds from the green fruits and fruits dried on the ground showed the low value of germination (Table 7). In the physiological maturation of the seeds it is reached the highest dry biomass accumulation, in this experiment the maturation stage was reached when the fruits were dried on the plant. The higher accumulation of dry biomass is attained to the physiological maturation and it can reach the higher vigor of the seed, however it depends on the species and genotype [22].

As the period of time that the fruits were on the ground, many process of damage occurred with it and probability damaged part of the breeding structure of the seed. This factor may be contributed by the less result in germination test.

The types of threshing showed that the seeds from the yellow and dried on the ground fruits are different in germination, the mechanical threshing decreased the germination in both stage of maturation (Table 8). These results were observed in the vigor test that means the first count of germination upon 5 days of sowed.

The right moment to harvest the fruits of Jatropha curcas L. is quite important to determine the physiology quality of seeds germination. The breeding of this species is by seeds and its physiological quality is the first step to obtain the adequate stand and good quality of the crop in the production field [23].

Table 7. Mean values of germination (\%) of Jatropha curcas L. seeds in different maturation stage, time of storage and method of threshing.

\begin{tabular}{ccccc}
\hline \multirow{2}{*}{ Maturation stage } & \multicolumn{3}{c}{ Storage time $^{\mathrm{a}}$} \\
\cline { 2 - 4 } Green & 0 day & 120 day & 240 day & Mean \\
Yellow & $82.00 \mathrm{aA}$ & $80.50 \mathrm{aA}$ & $51.67 \mathrm{bB}$ & $81.11 \mathrm{~A}$ \\
Ripe & $83.17 \mathrm{aA}$ & $77.33 \mathrm{aA}$ & $82.83 \mathrm{aA}$ & $83.06 \mathrm{~A}$ \\
Dried on the ground & $86.67 \mathrm{aA}$ & $84.83 \mathrm{aA}$ & $77.67 \mathrm{aA}$ & $71.00 \mathrm{aA} .05 \mathrm{~B}$ \\
Dried on the plant & $65.83 \mathrm{bA}$ & $58.33 \mathrm{bB}$ & $86.17 \mathrm{aA}$ & $88.00 \mathrm{~A}$ \\
Mean & $89.67 \mathrm{aA}$ & $88.17 \mathrm{aA}$ & $51.67 \mathrm{~b}$ & $80.50 \mathrm{a}$ \\
\hline
\end{tabular}

${ }^{\mathrm{a}}$ Mean in each line followed by the same lower case letter are not significantly different at $\mathrm{P}=0.05$ according to the Tukey test of mean. Mean in each column followed by the same capital letter are not significantly different at $\mathrm{P}=0.05$ according the to Tukey test of mean. $\mathrm{X}-$ lost treatment.

Table 8. Mean values of germination test (\%) of Jatropha curcas L. in manual and mechanical threshing and different stage of fruits maturation.

\begin{tabular}{ccccccc}
\hline \multirow{2}{*}{ Types of threshing } & \multicolumn{5}{c}{ Maturation stage of the fruits ${ }^{\mathrm{a}}$} \\
\cline { 2 - 6 } & Green & Yellow & Ripe & Dried on the ground & Dried on the plant & Mean \\
\hline Manual & $69.56 \mathrm{bA}$ & $91.89 \mathrm{aA}$ & $86.44 \mathrm{aA}$ & $72.11 \mathrm{bA}$ & $89.89 \mathrm{aA}$ & $81.98 \mathrm{~A}$ \\
Mechanical & $73.22 \mathrm{bA}$ & $70.33 \mathrm{bB}$ & $79.67 \mathrm{abA}$ & $58.00 \mathrm{cB}$ & $86.11 \mathrm{aA}$ & $73.47 \mathrm{~B}$ \\
Mean & $71.39 \mathrm{~b}$ & $81.11 \mathrm{a}$ & $83.06 \mathrm{a}$ & $65.06 \mathrm{~b}$ & $88.00 \mathrm{a}$ & \\
\hline
\end{tabular}

${ }^{\mathrm{a}}$ Mean in each line followed by the same lower case letter are not significantly different at $\mathrm{P}=0.05$ according to the Tukey test of mean. Mean in each column followed by the same capital letter are not significantly different at $\mathrm{P}=0.05$ according the t-test of mean. $\mathrm{X}$-lost treatment. 


\section{Conclusions}

Based on the results of this experiment, it is possible to recommend the harvest of yellow, ripe or dried plant fruits. By this way it is feasible to attain seeds with good physiological quality.

The manual threshing is indicated to preserve the physiological features of the Jatropha curcas L. seeds. The Jatropha curcas L. fruits when harvested in the adequate maturation stage (yellow, ripe or dried fruits on the plant) and threshing without mechanical damage can be stored by 240 days without decreasing the strength of germination. Irrespective of the threshing method and the maturation stage of the fruits, the Jatropha curcas L. seeds lose their vigor from 120 days, when these seeds are stored under the shadow in environment without moisture and air temperature control.

\section{Acknowledgements}

At UFGD and FUNDECT-MS, for the opportunity to accomplish the post graduation and the scholarship and financial support granted, respectively. To CNPq for research fellowships awarded. At Paradise Farm, by supporting this research.

\section{References}

[1] Saturnino, H.M., Pacheco, D.D., Gonçalves, N.P. and Lopes, H.F. (2005) Caracterização físico-química de alguns solos cultivados com pinhão manso no estado de Minas Gerais. In: Congresso Brasileiro De Plantas Oleaginosas, Óleos, Gorduras E Biodiesel, Biodiesel: Biocombustível Ecológico, Lavras, 5.

[2] Roscoe, R. and Silva, C.J. (2008) AGRIANUAL 2008: Anuário da Agricultura Brasileira. 1st Edition, FNP Consultoria e Comércio, São Paulo, 1-3.

[3] Borba, C.S., Andrade, R.V., Azevedo, J.T. and Oliveira, A.C. (1995) Qualidade de sementes de milho debulhadas com diferentes teores de umidade e fluxos de alimentação. Revista Brasileira de Sementes, 17, 9-12.

[4] Carvalho, N.M. and Nakagawa, J. (2000) Sementes: ciência, tecnologia e produção. 4th Edition, FUNEP, Jaboticabal, 356-460.

[5] BRASIL (2009) Ministério da Agricultura Pecuária e Abastecimento. Regras para Análise de Sementes. 1st Edition, MAPA, Brasília, 56-300.

[6] Association of Official Seed Analysts (1983) Seed Vigor Testing Handbook. 1st Edition, AOSA, East Lasing, 88.

[7] Hampton, J.G. and Tekrony, D.M. (1995) Handbook of Vigor Test Methods. 3rd Edition, ISTA, Zurich, 117.

[8] Dias, D.C.F.S., Bhering, M.C., Tokuhisa, D. and Hilst, P.C. (2006) Teste de condutividade elétrica para avaliação do vigor de sementes de cebola. Revista Brasileira de Sementes, 28, 154-162. http://dx.doi.org/10.1590/S0101-31222006000100022

[9] Dias, D.C.F.S. and Marcos Filho, J. (1995) Testes de vigor baseados na permeabilidade das membranas celulares: I. Condutividade elétrica. Informativo Abrates, 5, 26-36.

[10] Vanzolini, S. (1998) Teste de condutividade elétrica em sementes de amendoim (Arachis hypogea L.). Thesisofmasterdegreeat, Universidade Estadual Paulista, Botucatu.

[11] Vieira, R.D. and Krzyzanowski, F.C. (1999) Teste de condutividade elétrica. In: Krzyzanowski, F.C., Vieira, R.D., Neto, J.B.F., Eds., Vigor de sementes: Conceitos e testes, ABRATES, Londrina, 1, 1-26.

[12] Santos, H.G., Jacomine, P.K.T., Anjos, L.H.C., Oliveira, V.A., Oliveira, J.B., Coelho, M.R., Lumbreras, J.F. and Cunha, T.J.F. (2006) Sistema brasileiro de classificação de solos. 2nd Edition, EMBRAPA, Brasília, 102-133.

[13] SPSS (2001) Statistical Package for Social Sciences for Windows®. Version 11.0, SPSS Inc., Chicago.

[14] Nunes, C.F.N., Santos, D.N., Pasqual, M. and Valente, T.C.T. (2009) Morfologia externa de frutos, sementes e plântulas de pinhão manso. Pesquisa Agropecuária Brasileira, 44, 207-210. http://dx.doi.org/10.1590/S0100-204X2009000200014

[15] Saturnino, H.M., Pacheco, D.D., Kakida, J., Tominaga, N. and Gonçalves, N.P. (2005) Produção de oleaginosas para o biodiesel. Informe Agropecuário, 26, 44-74.

[16] Ruffato, S., Couto, S.M. and Queiroz, D.M. (2001) Análise de impactos em grãos de milho pelo método de elementos finitos. Revista Brasileira de Armazenamento, 26, 21-27.

[17] Terasawa, J.M., Panobianco, M., Possamai E. and Koehler, H.S. (2009) Antecipação da colheita na qualidade fisiológica de sementes de soja. Bragantia, 68, 765-773. http://dx.doi.org/10.1590/S0006-87052009000300025

[18] Vidigal, D.S. (2008) Alterações fisiológicas e bioquímicas em sementes de pimenta em função do estádio de maturação 
dos frutos. Thesis of máster degree at Universidade Federal de Viçosa, Viçosa.

[19] Corvello, W.B.V., Villela, F.A., Nedel, J.L. and Peske, S.T. (1999) Época de colheita e armazenamento de sementes de cedro (Cedrelafissilis Vell.). Revista Brasileira de Sementes, 21, 28-34.

[20] Albuquerque, F.A., Lucena, A.M.A., Oliveira, M.I.P., Andrade J.R., Beltrão, N.E.M. and Arriel, N.H.C. (2008) Aspectos fisiológicos de sementes de pinhão manso oriundas de frutos colhidos em diferentes estádios de maturação. 5th Edition, EMBRAPA, Campina Grande, 1-5.

[21] Horing, C.F. (2008) Influência do período de armazenamento na qualidade de sementes Jatropha curcas L. Thesis of master degree at Universidade Estadual do Oeste do Paraná, Marechal Cândido Rondon.

[22] Araujo, E.F., Araujo, R.F., Sofiatti, V. and da Silva, R.F. (2006) Qualidade fisiológica de sementes de milho-doce colhidas em diferentes épocas. Bragantia, 65, 5-14. http://dx.doi.org/10.1590/S0006-87052006000400020

[23] Pereira, M.D., Dias, D.C.F.S. and Dias, L.A.S. (2007) Germinação de sementes de Pinhão manso (Jatropha curcas L.) em diferentes temperaturas e substratos. In: Pereira, M.D., Ed., Congresso Da Rede Brasileira De Tecnologia De Biodiesel, MCT/ABIPTI, Brasilia, 6. 
Scientific Research Publishing (SCIRP) is one of the largest Open Access journal publishers. It is currently publishing more than 200 open access, online, peer-reviewed journals covering a wide range of academic disciplines. SCIRP serves the worldwide academic communities and contributes to the progress and application of science with its publication.

Other selected journals from SCIRP are listed as below. Submit your manuscript to us via either submit@scirp.org or Online Submission Portal.
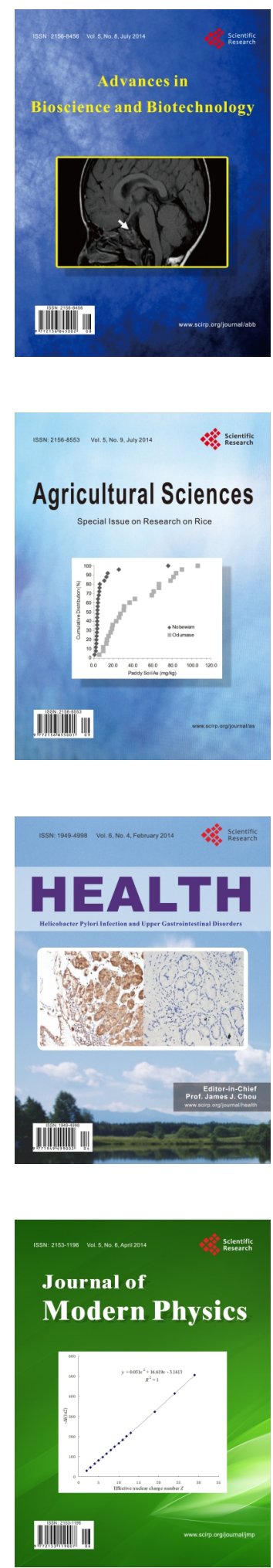
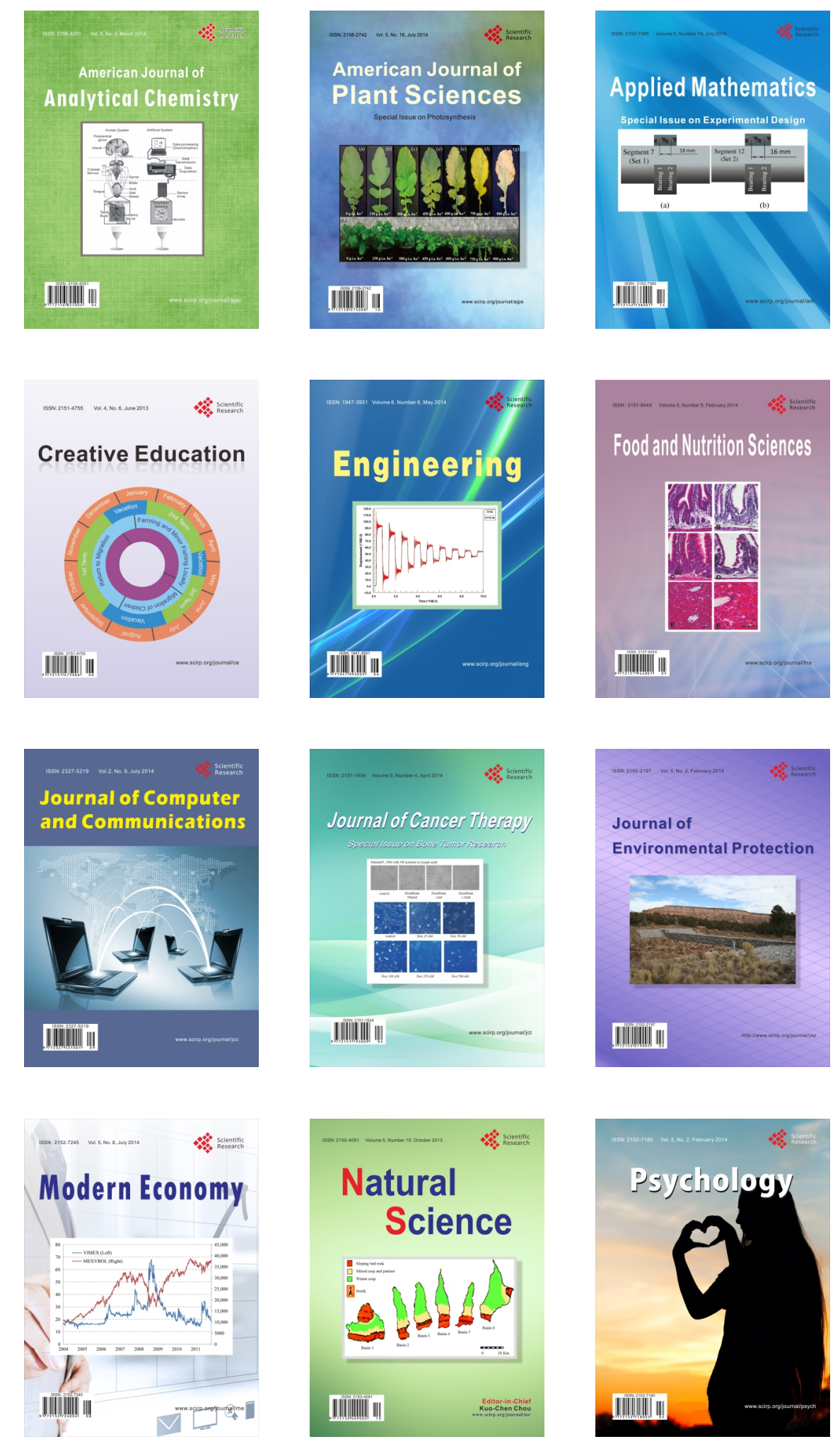